\title{
Æ Walachai
}

- husvildebarakker i Aabenraa 1922-1953

\section{af Orla Christiansen}

Gennem store dele af dette århundrede var husvildebarakker et af de midler, som blev taget $\mathrm{i}$ anvendelse mod boligmangelen. Ved Farversmøllevej i Aabenraas sydlige udkant byggedes der husvildebarakker i 1922. Mag. art. Orla Christiansen, Aabenraa, fortæller her om disse husvildebarakker - et hidtil upåagtet fænomen $i$ den nyere socialhistorie.

Hvordan og hvornår området ved Farversmøllevej, hvor barakkerne i sin tid lå, fik betegnelsen "æ walachai«, er der åbenbart ingen der ved mere. Meget taler dog for, at betegnelsen først blev knyttet til området hen imod slutningen af 30'erne, og at det var datidens ungdom på stedet, som selv gav området dette navn. I al fald kan min far, Harald P. C. Christiansen, som med korte mellemrum boede der fra 1932 til 1949, ikke huske, at barakkerne er blevet kaldt andet end »æ walachai«. Derimod ved den ældre generation på stedet at berette om, at bebyggelsen i folkemunde ofte gik under betegnelsen »Vridsløselille «; ${ }^{1}$ vel en hentydning til beboernes overgennemsnitlige kriminelle aktivitet.

Hvorfor bebyggelsen blandt ungdommen derude kom til at hedde »æ walachai«, lader sig næppe fastslå. At det imidlertid blev introduceret og brugt første gang af nogle af de skolesøgende piger, mener min far dog at kunne erindre, muligvis fordi det lød sjovt og helt anderledes og mere interessant end blot Farversmøllevej eller barakkerne. Men hvorfor netop betegnelsen $» \mathfrak{X}$ walachai«?

Geografisk og historisk er Valakiet, på tysk »die Walachei«, en del af Rumænien. Navnet på dette område mellem Karpaterne og Donau stammer helt tilbage fra det 12. århundrede, hvor de omkringboende nabofolk betegnede de romanske befolkningsgrupper, der efter folkevandringstiden havde bosat sig dér, som "valacher«, altså som nogle "vælske« typer, dvs. som fremmede og uforståelige, eller for at sige det med de ord dommeren i Aabenraa brugte i en udtalelse om beboerne i barakkerne til magistraten i 1930, wet eget Folkefærd . $^{2}$

Om denne etymologiske forklaring holder stik, ved jeg. selvsagt ikke. Man kunne imidlertid også tænke sig en anden mulighed, nemlig den, at ordet "walachei« på tysk jo også - med tydelig nedsættende betydning - bruges om et øde og fattigt område, og at det er det, pigerne har opsnappet et sted. Under alle omstændigheder er anvendelsen af ordet som betegnelse for husvildebarak- 
kerne i Aabenraa endnu et udtryk for, hvordan mange tyske ord trængte ind i byens sprog. Den slags germanismer var jo i sin tid ikke ualmindelige, og gav vel også først efter krigen anledning til hævede pegefingre, som da borgmester Georg Buchreitz ved synet af den i 1947 nedbrændte renovationsanstalt mente, at det nu endelig måtte være på tide at tage afsked med udtrykket »æ Abfuhr« (som renovationsanstalten dengang hed i folkemunde) til fordel for det efterhånden mere brugte danske udtryk $» \mathfrak{a}$ chokoladefabrik « ${ }^{3}$

Det er blevet hævdet, ${ }^{4}$ at barakfolket levede $i$ en egentlig "fattigdomskultur«, der på godt og ondt har påvirket deres liv. For langt hovedparten af beboerne gælder denne påstand dog ikke, dertil boede de $\mathrm{i}$ barakkerne i alt for kort tid. Udskiftningen i barakkerne var ret stor. Kun for henved $10 \%$ af familierne, nemlig den gruppe der udgjorde den »hårde kerne« og alene i kraft af varigheden af deres ophold blev normskabende, har det dog været tilfældet. Det er da også lige netop indenfor denne beboergruppe, at betegnelsen "walachai« for Farversmøllevej-barakkerne blev præget.

\section{Hvorfor beskæftige sig med barakkerne i Aabenraa?}

En af grundene til at beskæftige sig med Aabenraa-barakkerne, kan man aflæse i de officielle statistikker (jvf. tabel 1): intet sted i hele Nordslesvig var barakfænomenet nemlig så udbredt som i Aabenraa og - dog i mere beskedent omfang - i Haderslev. Derimod kendte man i Sønderborg og Tønder stort set ikke til fænomenet; vel nok fordi man begge disse steder allerede meget tidligt fik løst husvildeproblemet igennem en storstilet byggeaktivitet. ${ }^{5}$

En anden grund, som gjorde, at jeg simpelthen måtte have stillet min nysgerrighed igennem arkivstudier, har været min fars medrivende og i den grad levende fortællinger om sin tid derude, fortællinger som $\mathrm{i}$ alt, hvad jeg har kunnet kontrollere, har vist sig at være i fuld overensstemmelse med de fakta,

Tabel 1. Antallet af lejligheder $i$ barakker, lysthuse m.v. $i$

\begin{tabular}{lccllll}
\hline & 1924 & 1925 & 1926 & 1927 & 1928 & 1929 \\
\hline Aabenraa & $36(69 \%)$ & $32(74 \%)$ & $42(67 \%)$ & $13(69 \%)$ & $47(94 \%)$ & $32(76 \%)$ \\
Haderslev & $11(21 \%)$ & $9(21 \%)$ & $21(33 \%)$ & & $3(6 \%)$ & $10(24 \%)$ \\
Løgumkloster & $4(8 \%)$ & & - & & - & - \\
Sønderborg & & $2(5 \%)$ & - & $1(5 \%)$ & - & - \\
Tønder & $1(2 \%)$ & & - & $5(26 \%)$ & - & - \\
\hline Ialt & $52(100 \%)$ & $43(100 \%)$ & $63(100 \%)$ & $19(100)$ & $50(100 \%)$ & $42(100 \%)$ \\
\hline
\end{tabular}

Kilde: Statistiske Meddelelser, 4. Række: Husleje og Boligforhold, Nov. 1924-1929, Danmarks Statistik 1925-30. 
arkiverne indeholdt; uden at disse dog kan siges at have fundet deres adækvate indgang i den tilgængelige litteratur. Det være sig Aabenraa Bys Historie, men i særlig grad den meget skuffende bog af Fred Vilhelm Schmidt »Fra de røde barakker« (Attika, 1993). ${ }^{6}$ Bl.a. for at afhjælpe denne mangel er nærværende opsats blevet skrevet.

I det følgende vil jeg søge at vise, hvordan udviklingen er foregået; hvordan bystyret $\mathrm{og}$ forvaltningen har set på og har behandlet barak-folket; og hvordan beboerne $i$ barakkerne selv har opfattet tingene. Ganske vist er temaet kun en lille brik i den historiske udvikling, og dog må det være interessant at undersøge, hvordan samfundet har behandlet - og ind imellem fortsat behandler sine ydergrupper i spændingsfeltet mellem armod og fattigvæsenet. Kanske at historien hverken skrives eller formes af - eller med henblik på - de "små《 i samfundet. Men det bør ikke medføre, at netop deres historie glemmes - og gemmes bort.

Da Aabenraa kommune i 1922 traf beslutning om at placere sine nye husvildebarakker derude, et par kilometer syd-vest for byen, hvor idag Andelsboligforeningens boligblokke på Fuglsang ligger, skete det sikkert ud fra den opfat-

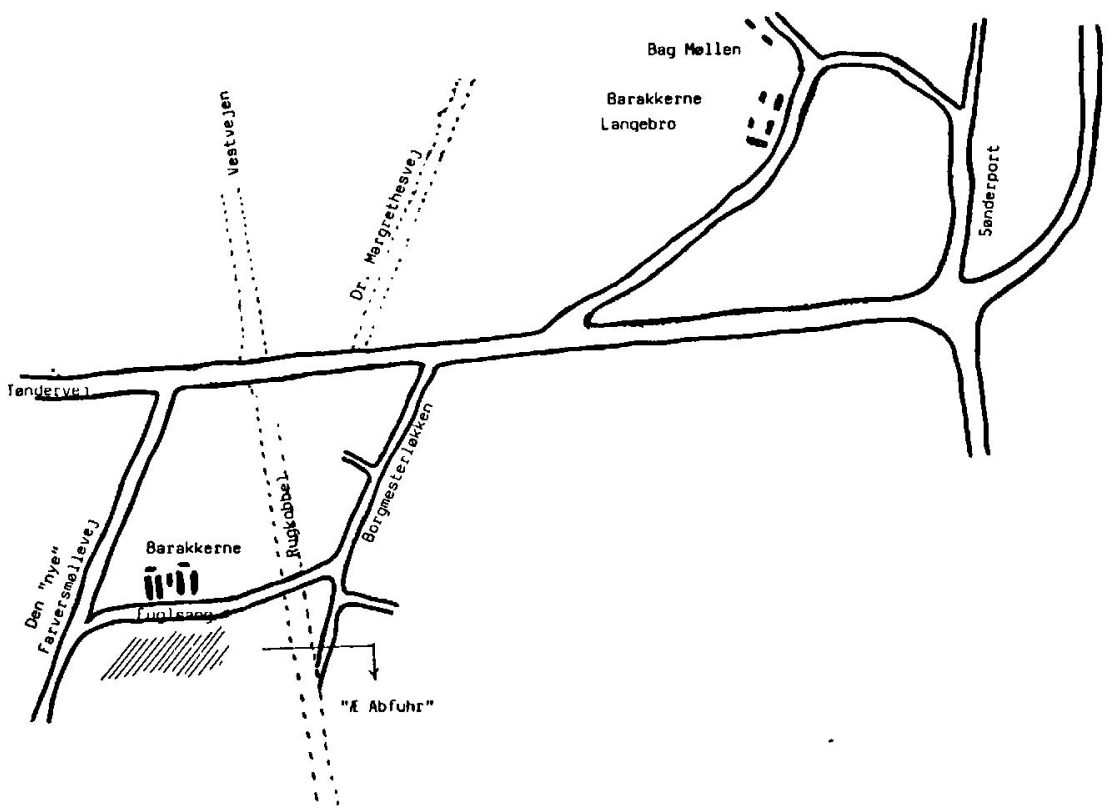

Plan over beliggenheden af barakkerne ved Farversmollevej. Hvad der pd planen idag barer navnene Fuglsang og Borgmesterlokken hed tidligere Farversmollevej. Den mnyer Farversmollevej pd planen er vejen op til Farversmellevej. 
telse, at den slags folk bedst kunne anbringes så langt borte - klos op af »æ Abfuhru.

Det "nye« ved disse barakker var ikke, at de var de eneste $\mathrm{i}$ byen; thi på dette tidspunkt fandtes der allerede husvildebarakker ved Skibbroen, ved Sønderport og i Højgade. Nej! Det "nye« var, at de for det første udgjorde det seneste skud på stammen af nødboliger og for det andet, at de denne gang blev placeret så langt uden for byen - og samtidig dermed så langt borte fra de "anstændige folk «, at bedsteborgerne ikke uafbrudt blev mindet om lige præcis denne del af samfundets udskud. Eller, som den tidligere amtsborgmester Erik Jessen så rammende har formuleret det: "Placeringen ved Farversmøllevej ... var udtryk for, at "den slags folk « kunne man ikke have boende $i$ nærheden af »anstændige folk «. ${ }^{7}$

Det samme gjaldt også for de i 1923 opførte stenbarakker ved Bag Møllen og lidt senere igen - nemlig omkring 1925 - for barakkerne ved Langebro.

Tendensen med at flytte husvildeboligerne så langt uden for byen som overhovedet muligt, blev igen understreget i 1929, da træbarakken ved Skibbroen blev flyttet over på Lindsnakke.

lkke alle nødboliger $i$ træbarakker blev imidlertid også opfattet som egentlige husvildeboliger. Der var åbenbart en vis lagdeling af bolignøden som gjorde, at nogle af nødboligerne i Aabenraa, som Erik Jessen har sagt, "nok blev anset for at være lidt finere end « andre. Noget som for øvrigt også kom til udtryk i kommunens officielle indberetninger til Indenrigsministeriet om boligforholdene $\mathrm{i}$ kommunen, da de startede i 1921. Ifølge disse skal Aabenraa i perioden fra 1921 til efter efterårsflytningen i 1923 nemlig overhovedet ikke have haft familier boende i barakker eller i andre midlertidige lejligheder. ${ }^{8}$ Dette stemte dog ikke overens med de faktiske forhold, sådan som de fremtræder for os $i$ arkiverne. I al fald udviser en fortegnelse (til internt brug i forvaltningen) af 15. aug. 1923, at ialt 14 familier på dette tidspunkt boede i husvildebarakker ved Farversmøllevej; et tal der ved årsskiftet var steget til $16{ }^{9}$ Derudover fortegnede byens adressebog, at der på samme tid boede 8 partier i en husvildebarak på Skibbroen. Hvad man her imidlertid fortier, er, at der på samme tid lå træbarakker i Højgade og Sønderport, som sammen med nødboligerne ved Bag Møllen og Langebro, og senere igen husvildeboligerne på Sønderskovvejen, da de stod færdige i 1943-44, aldrig nogen sinde blev gjort til genstand for indberetning. De havde således ikke officiel status af egentlige husvildeboliger.

I det følgende vil jeg derfor kun undtagelsesvis komme ind på disse "finere« nødboliger, for desto mere at kunne koncentrere mig om beskrivelsen af selve Farversmøllevej-barakkernes tidlige og tidligste historie, netop fordi det først og fremmest var dem, der i Aabenraa kommune kom til at optræde som husvildeboligerne slet og ret (sammen med træbarakken ved Skibbroen/Lindsnakke). 


\section{Barakkerne ved Farversmøllevej}

Barakkerne ved Farversmøllevej blev opført ad to omgange. De første to af kompleksets ialt fire beboelsesbarakker blev udliciteret i 1922, de sidste to i 1924.

Barakkerne var rødmalede træbarakker med paptag uden tagrender. Hver af barakkerne indeholdt 8 »lejligheder«, 6 med hver 2 rum (ét værelse og køkken), og 2 med hver 3 rum. I størrelse varierede de fra $18,84 \mathrm{~m}^{2} \mathrm{hhv} .21,24 \mathrm{~m}^{2}$ for de to rums til $31,23 \mathrm{~m}^{2}$ for de 3-rums lejligheder. På langsiden imellem de to første barakker, der stod færdige til indflytning i januar 1923 lå en $90 \mathrm{~m}^{2}$ stor barak med lejlighedernes latriner, to fælles vaskerum med kedler og beboernes brændsels- og pulterkamre. De to sidste barakker, som stod færdige til indflytning i juli $1924,{ }^{10}$ blev opført hhv. øst og vest for de to første, hver med sin egen $45 \mathrm{~m}^{2}$ store barak til latriner m.v. placeret overfor beboelsesbarakkernes nordlige gavlende. ${ }^{11}$

Offentliggorelsen af de indkomne tilbud pd opforelsen af de kommunale husvildeboliger ved Farversmollevej $i$ Hejmdal den 15.11.1922.

\section{De un komumuale Susvilbeboliger.}

Sicifafionen over Opiereffen.

\$aa IJurer, Ismrer॰, Snebler., Blarmejter. og Malerarbejbet veb Dpforelfen. of be to nue tommunale Gusvilbeboliger er ber indommen for. gende Iilbud:

IR urers og Iomrecarbefbet: थ. Ro. renzen 19,235.93 Sironer, D. Dethiefifen 19,359.65

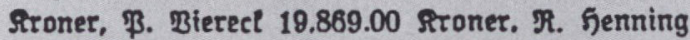
20,134.40 ironer, 5. TR. Earenien 21,533.00 9ro

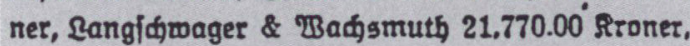
R. Brie 22.224.64 Rroner.

Eneblerarbeioet: Entonien \& Chrift: anlen 4316 Rronet, Burract 4576 sironer. Joh. Beterien 4580 Proner, Davids \& Janien 4645 Sironer, Ehr. Beterfen 4740 Stoner.

B f a rmeft z r ar be i bet: Fendenteid \& Ei. vertien 207 groner.

Il alerarbeibet: Falct 788.23 froner, Joer Ganien 958.80 Sironer. Dlanb 1037.60 Siro. ner, Ferløo Mefter 1280 fironer. Claujen 1292.90 Sroner, Dtto Claslen 1330 stroner, Niels R. Niel. ien 1900 sironer.

ทีย थै थrbejoet un ber et: D. Dethlef: fen 23.653.65 fironer, 24 . Sorenzen 25,178.83 Siro. ner. . Bierect $26,021.00$ Rroner. 


\section{Om baggrunden for deres opførelse}

At også Aabenraa - som følge af krigen - var plaget af bolignød i begyndelsen af 20'erne, er klart nok; ellers havde byen jo ikke haft sine træbarakker, hvortil kom de øvrige indkvarteringer i den fhv. navigationsskole i Bjerggade, $i$ et par gymnastiksale og i »æ Flye' halle«, de senere eksportstalde. Men noget egentligt akut behov for yderligere husvildeboliger havde byen næppe, da beslutningen om at opføre barakkerne ved Farversmøllevej blev truffet. At de alligevel blev bygget, skal nok ses i sammenhæng med de ændringer i den gældende boliglovgivning, som på dette tidspunkt blev gennemført.

Siden huslejereguleringen var blevet indført ved lov af 9.6.1916 var ordningen år efter år blevet forlænget for - $\mathrm{i}$ et marked, hvor ingen private alligevel turde bygge - at beskytte lejerne i de gamle ejendomme mod urimelige huslejestigninger. Således også i loven af 1.4.1921 og ét år frem. Kort forinden loven udløb i 1922, gennemførte Indenrigsministeriet et rundspørge til samtlige byog landkommuner, der havde oprettet huslejenævn, for at få et overblik over, hvor mange af disse der ønskede huslejereguleringen opretholdt. Af de 84 byog 314 landkommuner, hvor nævnet eksisterede, ønskede 71 og 241 af kommunerne den stadig fortsat. ${ }^{12}$ I lyset af de siden 1920 stigende obligationskurser og det siden 1921 igangværende opsving i det private byggeri, som varede ved til og med 1923, tog folketinget imidlertid kun delvis kommunernes ønsker til efterretning. Ganske vist bevaredes huslejenævnene i loven af 1.5.1922, men samtidig blev deres indflydelse drastisk beskåret, idet de for fremtiden ikke mere skulle give deres samtykke til "Overenskomster mellem Ejer og Lejer om Forhøjelse af Lejen i et bestaaende Lejeforhold«, men kun ved indgåelsen af nye lejemål, altså alle lejemål, hvor nye lejere flyttede ind i såvel den gamle som i den nye boligmasse.

Umiddelbart ser dẹne ændring i boligloven ikke ud til at have afstedkommet noget yderligere behov for husvildeboliger i Aabenraa. Tværtimod udviser kommunens officielle indberetninger om boligforholdene $\mathrm{i}$ byen, at der hverken i 1921, 1922 og 1923 var personer under kommunal boligforsorg, ja, at der på opgørelsestidspunktet $\mathrm{i}$ november måned endda var hhv. 5 og 6 lejligheder ledige i byen i 1922 og $1923 .{ }^{13}$ At kommunen dermed bevidst fortiede tilstedeværelsen af $i$ al fald 5 familier, som på dette tidspunkt beboede husvildebarakken ved Skibbroen (og 7 andre familier, hvis vi tæller de øvrige træbarakker ved Skibbroen og Sønderport med) i 1922, og i al fald 7 familier, som i 1923 beboede husvildebarakken ved Skibbroen (og 4 andre familier, hvis vi også her tæller træbarakken ved Sønderport med), er imidlertid en kendsgerning. ${ }^{14}$ Tæller vi derudover beboerne i husvildebarakkerne ved Farversmøllevej med, som boede der pr. 30. november 1923, skal der endda lagges yderligere 16 
familier til, som heller ikke er blevet indberettet som personer under kommunal boligforsorg. Hvad end baggrunden for denne tavshed $i$ indberetningerne må have været, så er det dog påfaldende, at indberetningerne først fra og med april måned 1924 registrerer personer under kommunal boligforsorg, og da sågar med hele 30 familier (heraf de 20 ved Farversmøllevej, 2 i den fhv. navigationsskole og 8 ved Skibbroen). ${ }^{15}$ Påfaldende fordi boliglovgivningens bestemmelser omkring huslejereguleringen, som Aabenraa byråd helst havde set fortsat et godt stykke tid endnu, netop faldt bort den 1.5.1924 med fuldstændig afvikling året efter. Måske tilbageholdt Aabenraa kommune tallene over personer under kommunal boligforsorg så længe, for derigennem at »dokumentere" den hidtidige lovgivnings hensigtsmæssighed og ønskeligheden i, ja nødvendigheden af dens fortsættelse.

Allerede på byrådets møde den 23. jan. 1924 havde borgmester Holger Fink slået til lyd for, at den gældende bogliglov burde bibeholdes windtil Krigens Eftervirkninger er helt overvundne«. Også huslejenævnet havde anbefalet, wat Loven forlænges«. Endda husejerrepræsentanterne kunne, ifølge Holger Fink, "tiltræde, at Opsigelse (skulle) godkendes af et nedsat Nævn«. I modsat fald ville følgen «af Lovens Ophævelse ... blive, at en hel Del Familier med mange Børn (ville blive) husvilde, og Kommunen (blive tvunget til) kommunalt Byggeri«. Og borgmesteren fortsatte:

"Bliver der frit Slag, regner vi med, at Kommunen faar 50-80 Husvilde, der vil melde sig i Løbet af et kvart Aar. Loven betyder en ensidig Begunstigelse af Lejerne, men Nødsituationen tvinger os, og jeg kan kun stemme for at gøre, hvad der staar i vor Magt for at faa de indskrænkende Bestemmelser bibeholdt. Den økonomiske Konsekvens af Lovens ophør er, at vi i Løbet af Sommeren bliver nødt til at fremsætte Forslag om Opførelsen af 60-70 Nødboliger ${ }^{16}$

Netop dramatikken i disse ord, skulle indberetningerne fra april måned 1924 og fremefter formentlig understrege!

\section{De første indflyttere}

Når kommunen i 1922-23 havde brug for husvildeboliger, så var det ikke så meget fordi der stod lejere uden egentligt tag over hovedet, men fordi kommunen manglede et sted at anbringe de lejere i kommunens øvrige ejendomme, som ikke betalte deres husleje og derfor burde udsættes. En opgørelse, som 
kommunen udfærdigede, da barakkerne blev meldt klar til indflytning, viser at ialt $\mathbf{1 4}$ familier var udset til at skulle flytte til den nye adresse. Heraf var de 8 allerede indstillet til udsættelse. Om de resterende 6 familier fastslog kommunen, at de måske ville betale, hvis de blev truet med at få anvist en bolig i de nye husvildebarakker, hvilket da også ser ud til at have virket. ${ }^{17}$

Den første bølge af indflyttere talte 28 lejepartier i perioden fra febr. 1923 til juli 1924. Heraf fraflyttede igen de $12 \mathrm{i}$ den samme periode. Selv om det med sikkerhed kun kan siges om ca. $20 \%$ af disse lejere, at de måtte flytte ud i barakkerne ved Farversmøllevej på grund af huslejerestancer, så indikerer den almindelige betalingsmoral hos indflytterne, at dette nok har været tilfældet for $\mathrm{i}$ al fald henved $80 \%$ af beboerne.

Af disse 28 første familier, har jeg for de 6 ikke kunnet finde deres tidligere adresse. Af de resterende 22 familier kom de 6 fra andre af kommunens ejendomme $\mathrm{i}$ byen. To andre familier måtte flytte derud, fordi deres tidligere bolig måtte vige pladsen for et nybyggeri i Kolstrup. Én familie kom fra Gildegade, én fra Bag Møllen, én fra Storegade, to fra Lindsnakke, fire fra Slotsgade (heraf de to fra Slotsgade 14, hvis fire 2-værelseslejligheder i baghuset i oktober måned 1928 blev erklæret for ubeboelige - og derfor nok også i 1923-24 har været uegnede til beboelse), ${ }^{18}$ to fra Sønderport, og tre familier, der kom udenbys fra. ${ }^{19}$

Når jeg her så pedantisk har gjort rede for de første indflytteres boligmæssige herkomst, så er det fordi én af de tidligere beboere $\mathrm{i}$ barakkerne ved Farversmøllevej, nemlig den navnkundige "general Schmidts« søn, Fred Vilhelm Schmidt, i sine erindringer har givet udtryk for, at barakkerne først og fremmest blev bygget for at skaffe boliger til udflyttere fra byens svampekratere i Slotsgade og Sønderport. ${ }^{20}$ Fastslås kan det, at henad 25\% af indflytterne frem til den 18.7.1924 vitterligt kom fra hhv. Sønderport og Slotsgade, men dog altså kun ca. $7 \%$ fra lejligheder, der på dette tidspunkt har været direkte usunde eller faldefærdige og dermed uegnede til beboelse - set fra sundhedskommissionens synspunkt! En tilsvarende procentsats galder for de indflyttere, der kom til at bo i barakkerne i 1924-25, idet jeg for denne periode kun har fundet én lejer, der måtte flytte derud pga. sin lejligheds ubeboelighed.

Hvor lidt udtalt bolignøden i Aabenraa egentlig var på dette tidspunkt, kan man f.eks. se deraf, at der gik halvanden måned fra færdiggørelsen af 2 . etape og frem til, at de første lejere flyttede ind. De første tre familier flyttede ind den 1.9.1924. I de følgende fire måneder fulgte tolv lejere efter. Af disse femten familier, kom de seks meget hurtigt i huslejerestance; hvilket dog ikke på nogen måde kom bag på kommunen, idet den ved beslutningen om at opføre 2. etape netop havde understreget, at 
»disse Lejligheder - saaledes som Forholdene i Øjeblikket er væsentligst vil blive beboede af Familier, der sættes ud af deres Lejligheder af Kongens Foged paa Grund af Huslejerestancer, og som heller ikke hos Kommunen, efter de hidtil gjorte Erfaringer at dømme, er villige til at betale Husleje«. ${ }^{21}$

En tendens, som ikke just blev mindre med årene. Tværtimod!

\section{Kampen om huslejen}

I den første tid var barakkerne plaget af stor fugtighed. I al fald klagede lejerne $\mathrm{i}$ juni 1923 over, at fugten ødelagde både deres møbler, billederne på væggene, ja i øvrigt alt hvad de ejede og havde, hvorfor de mente, at den forlangte husleje var ublu og burde nedsattes straks, til ikke over kr. 180,- pr. år for de 2-værelses og kr. 120,- for de 1-værelses lejligheder. Da den årlige leje lå på hhv. kr. 260,- og kr. 200,- pr. år, svarede dette til en huslejereduktion på $31 \%$ og $40 \%$. Til gengæld for kommunens accept af denne huslejenedsættelse tilbød beboerne på deres side, at de fremover ville betale såvel huslejen som de allerede oparbejdede restancer; i modsat fald »betaler vi ikke noget«, lød truslen fra beboerne!

Klagen blev dog ikke taget til følge af magistraten. Lejen stod i et rimeligt forhold til det lejedes værdi, mente kommunen; en påstand, kommunen - alt taget $\mathrm{i}$ betragtning - ganske sikkert havde ret $\mathrm{i}$.

Denne beslutning var lejerne imidlertid ikke sådan uden videre til sinds at affinde sig med, hvorfor en slags huslejeboykot blev sat i værk. Stort set samtlige lejere holdt nu inde med betalingerne. Enkelte havde endog slet ikke betalt en krone i husleje, siden de var flyttet ind, eller de var holdt op med at betale allerede fra begyndelsen af april måned 1923. Atter andre havde valgt at betale et mindre, mere symbolsk beløb i husleje.

At kommunen ikke $i$ længden kunne tolerere en sådan undergravende adfærd, siger sig selv. Den måtte reagere, håndfast og bestemt. Reaktionen kom den 17. aug. 1923 i et brev fra kommunen til beboerne, som nu skulle knækkes. I brevet truer kommunen de implicerede med udpantning og alle ellers til rådighed stående tvangsmidler. Da dette imidlertid ikke frugtede, udgik der den 6. sept. 1923 på ny brev fra kommunen til lejerne, om at såfremt de ikke inden den 15.9.1923 havde betalt den skyldige leje eller et afdrag til dens nedbringelse, ville restancerne blive dækket af fattigvæsenet "med Fattighjælps virkning for Dem«.

Men ej heller dette brev gjorde større indtryk, hvorfor kommunen i 
nov. - dec. ikke så anden udvej, end at anmode "det ærede Fogedkontor om at ville foranledige "de skyldige« "udsat af « deres lejligheder. Denne sidste besked udgik målrettet til tre af lejerne, hvoraf de to havde fundet deres vej til barakkerne pga. huslejerestancer og med fogedens mellemkomst. Til disse indeholdt brevet fra kommunen da også den yderligere tilføjelse, "at man (ville) holde et Rum paa Kommunens Fattiggaard rede til at optage ' dem. Alvoren i denne henvendelse blev yderligere understreget af, at kommunen samtidig havde betalt stempel - og retsgebyr til dækning af den evt. udsættelsesforretning.

Først nu reagerede lejerne. Hovedmanden betalte herefter meget hurtigt kr. 117,- af på sin restance, hvorefter han imidlertid stadig var kr. 17,- skyldig, svarende til én måneds husleje. Den anden af hovedmændene mødte op på kommunen dagen efter, at han havde modtaget meddelelsen om den indleverede udsættelsesbegaring, hvor han betalte novemberhuslejen og samtidig traf aftale om at afdrage restbeløbet på kr. 138,15 med kr. 10,- pr. uge (svarende til ca. $20 \%$ af sin løn) i de perioder, hvor han havde arbejde, og ellers med kr. 5,- pr. uge. Lignende ordninger blev snart efter også truffet med de øvrige restanter, dog uden at restancerne af den grund blev væsentligt mindre. Tværtimod. I stedet for at gå ned, steg restancerne fortsat, på trods af de indgåede aftaler.

Hvor udtalt et problem gældsætningen i den første periode var, fremgår af at den beregnede husleje frem til den 1.7.1924, på rundt kr. 2.440 stod overfor en samlet gæld på ikke mindre end kr. 2.200. Eller sagt på en anden måde: beboerne havde kun betalt $9,8 \%$ af den faktisk beregnede lejeindtægt til kommunen.

Det kan, på denne baggrund ikke undre, at kommunens bogligudvalg efterhånden måtte nå frem til den slutning, wat Beboerne af Barakkerne ved Renovationsanstalten ", "aabenbart er kommet ind paa ikke at ville betale Husleje, ganske uanset om Evnen er til Stede eller ej«, og at man af den grund »formentlig bør gøre alt muligt for at hindre, at denne Tilbøjelighed breder sig til Kommunens øvrige Lejere«, hvorfor udvalget da også endnu en gang mente at skulle henstille til magistraten, wat den saaledes erhvervede Huslejehjælp (blev givet) Fattighjælps Virkning i alle saadanne Tilfælde, hvor Magistraten (var) overbevist om, at god Villie ikke (var) til Stede«. Henstillingen blev taget til følge af magistraten, hvorefter der afgik brev til lejeboykotens hårde kerne. I brevet hedder det, "at Magistraten nødvendigvis maa hælde til den Anskuelse, at Betalingsviljen mangler«; at man nu "for sidste Gang (opfordrer Dem) til at betale den løbende Leje og afdrage Restancen med $5 \mathrm{kr}$. om Ugen «; at der ville blive »ført nøje Kontrol med, hvormeget» den enkelte betaler; og at restancerne, "saafremt man herefter 

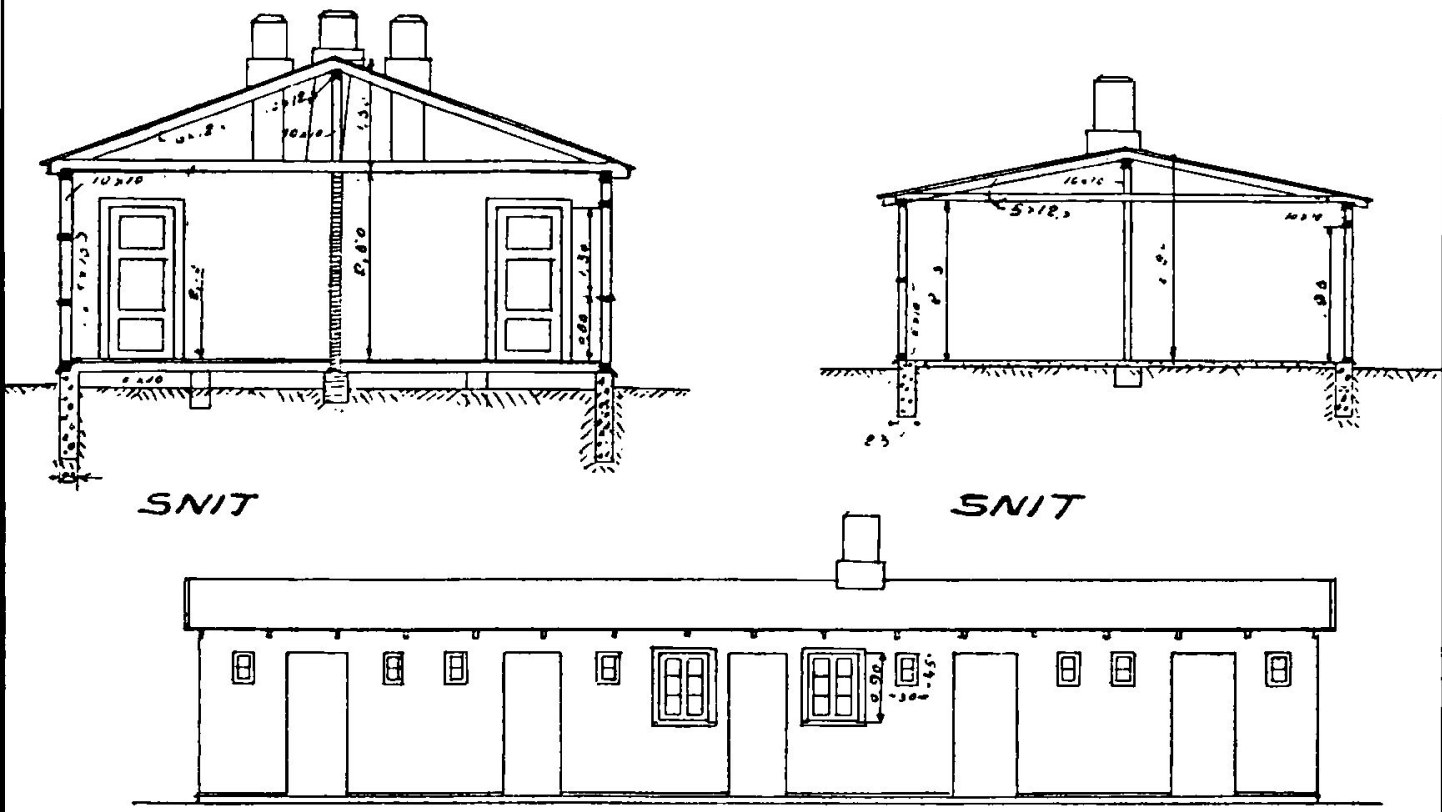

SIOE

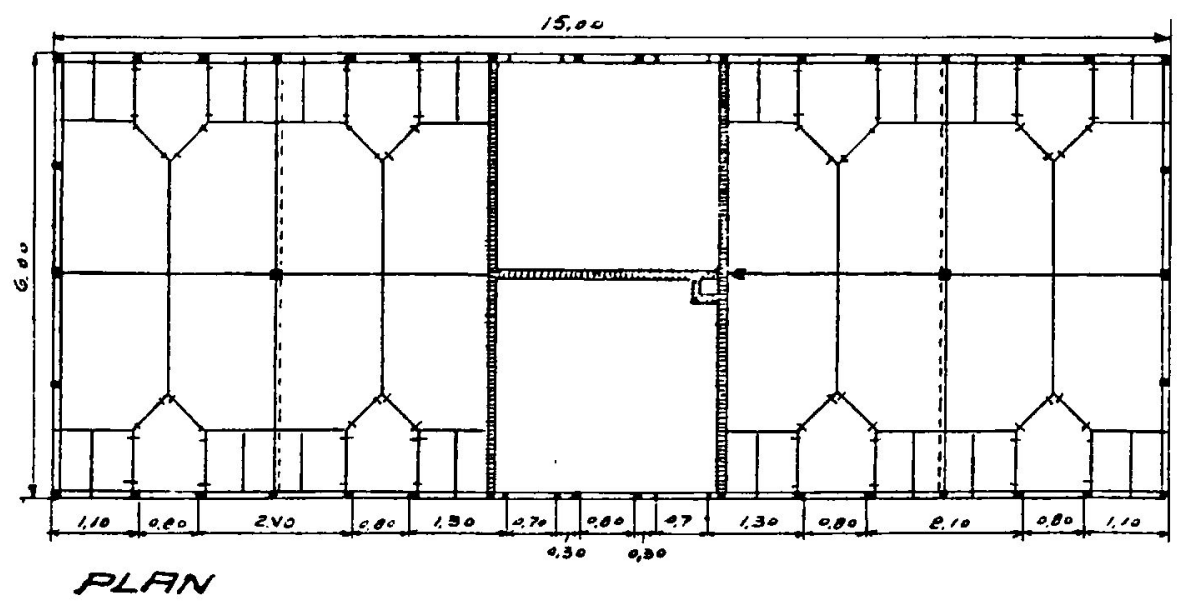

Aobersaa, Novbr. 1922

Husvildeboligerne. Snit og plan. 1922. Aabenraa byarkiv 1920-70 pk. 11-2. 
maa skønne, at »der ikke betales »efter Evne«, nu ville »blive udredet af Fattigvæsenet med Fattighjælps Virkning " for den enkelte. "Dette betyder «, hedder det videre i skrivelsen, "at De mister Deres Valgret og senere Deres Ret til Nydelse af Aldersrente. Endvidere vil Kommunen, som det hedder i slutningen af brevet, "med alle til Raadighed staaende Midler (Afsoning m.m.) kræve den evt. gennem Fattigvæsenet ydede Huslejehjælp refunderet.$^{22}$

Dermed var linien lagt for kommunens videre fremfærd i sagen. Men ej heller disse yderligere trusler ud i fortabelsen af valgretten til såvel de kommunale råd som til rigsdagens to kamre, folketinget og landstinget, såvel som fortabelsen af retten til aldersrente, ser ud til at have haft den helt store virkning. Imidlertid tilgik der byrådssekretæren et brev, dateret den 25.8.1924, hvori denne fik besked om, at boligudvalget havde vedtaget »endnu at se Tiden an til 1. Oktober « førend man ville gå over til at "lade Huslejerestancerne betale af Fattigkassen«, ligesom det først derefter nærmere skulle overvejes, "hvad man videre (ville) foretage (sig) mod de paagældende«.

Det endelige punktum i sagen blev sat, da kommunen den 13.1.1925 traf beslutning om, at alle restancer, med skæringsdagen 1.7.1924, nu skulle betales af fattigvæsenet »med Virkning som Fattighjælp«.

Snart efter ændrede byrådet dog kurs. I februar 1926 besluttedes, at huslejen skulle nedsættes fra de oprindelige kr. 260 og 200 til hhv. kr. 225 og 150 årligt fra 1 . april 1926 at regne.

Hvad årsagerne til denne kursændring end kan have været, så viser det statistiske materiale, at kommunens huslejefastsættelse for lejlighederne faktisk kunne betegnes som ublu, idet nemlig huslejeniveauet i kommunen for 1og 2-værelseslejligheder generelt lå noget under det, som kommunen forlangte af lejerne ved Farversmøllevej. Således lå huslejen i barakkerne for 1-værelseslejlighederne i 1923 og 1924 14,3\% over det generelle huslejeniveau i byen. For 2-værelseslejlighederne lå huslejen i barakkerne i 1923 endda $15,6 \%$ over byens generelle huslejeniveau. Først i 1926 faldt huslejen i barakkerne under byens generelle niveau.

At huslejereduktionen i barakkerne i 1926 hang sammen med den foregående lejeraktion, kan man selvfølgelig ikke helt afvise; men jeg tror det ikke. Ej heller tror jeg, at den var udtryk for, at kommunen nu endelig havde făet øjnene op for, at den oprindelige huslejefastsættelse havde været for høj, selv om både dommer Andersen og Holger Fink på byrådsmødet den 23. jan. 1924 havde været rørende enige om, at der wher i Byen i stor Udstrækning er taget meget mere i Leje end nødvendigt «, dels fordi "mange Lejligheder var saa slette, at Lejlighederne ikke skulde have betalt nogen Leje« og dels fordi "Generation efter Generation af Lejere var rykket ind i Lejlighederne, uden 
at der var blevet gjort noget ved Ejendommene ${ }^{23}$ Nej, reduktionen skyldtes snarere, at udviklingen i samfundet generelt påbød gennemførelse af lavere huslejer i kølvandet på den af finansminister Bramsnæs førte deflationspolitik og den heraf bevirkede betydelige arbejdsløshed, som jo især mange $\mathrm{i}$ barakkerne blev ramt af.

Ser vi nærmere på huslejen $\mathrm{i}$ barakkerne, så faldt den allerede igen året efter, altså pr. 1.4.1927; vel sagtens, fordi hovedparten af lejerne derude $i$ ganske særlig grad blev ramt af de faldende indtægter og arbejdsløshed. Denne gang faldt de med ca. $20 \%$. Med virkning fra d. 1.12 .1929 blev lejen igen nedsat. Denne gang med ca. 10\%. Fra at være blevet opkrævet månedsvis bagud siden 1923, og senere månedsvis forud, blev det nu ydermere besluttet at opkræve huslejen ugevis, ikke som tidligere ved kommunens kassebud, og senere ved fremmøde på kommunekontoret, men af "Forsørgelseskontoret paa Stedet hver Lørdag Formiddag«. Forsørgelseskontoret blev indrettet $i$ en af barakkernes 1-værelses lejligheder på adressen Farversmøllevej 36.

Med de indførte ændringer kostede nu fremover de 1-værelses lejligheder kr. 2,- pr. uge. De 2-værelses kr. 3,- pr. uge. Var man lejer af to 1-værelses lejligheder, og det var op til otte familier pga. disse familiers store børnerigelighed, skulle der nu istedet for kr. 232,- pr år kun udredes ialt kr. 182 svarende til kr. 3,50 pr. uge. Denne sidste huslejeændring kom vistnok til at galde helt frem til barakkernes endelige nedrivning i 1953, altså i hele 22 år!!

Udover disse forandringer, blev der endvidere fra 1929 fastskrevet følgende betingelser for lejemålene i barakkerne:

a) Husleje, der ikke betales rettidigt, vil blive udlagt forskudsvis af Forsørgelsesvæsenet som Fattighjælp med de deraf for Dem følgende Virkninger.

b) For lejere, der modtager ugentlig fattighjælp til underhold, skal lejen fradrages hjælpen ved udbetalingen hver tirsdag.

c) Har en lejer arbejde ved kommunen, skal lejen fremover fradrages ugentligt i arbejdslønnen ved Stadsingeniør-, Gasværks- eller også Kæmnerkontorets Foranstaltning og af disse afleveres til Forsørgelseskontoret til Bogføring og Afregning.

d) For lejere, der ikke betaler deres husleje, og som ikke har nogen aftale med kommunen, opsiges lejemålet med 14 dages varsel.

e) Lejere der, på trods af en sådan opsigelse, ikke fraflytter deres lejlighed $\mathrm{i}$ husvildebarakkerne (og hvor skulle de da også flytte hen, når de således var blevet husvilde?), ville (da straf jo skulle være) blive omflyttet til »en af de 2 vestlige Barakker«, samtidig med at »Huslejen for disse Lejere« fremover skulle »udredes af Fattigkassen ${ }^{24}$ 


\section{Beboerne}

Ifølge de officielle indberetninger om boligforholdene i Aabenraa var der i tidsrummet fra 1924 til 1928 i gennemsnit anbragt 29 familier (143 personer, hvoraf de 74 var børn under 15 år) i kommunens husvildebarakker. Af disse boede langt hovedparten i barakkerne ved Farversmøllevej. I træbarakken ved Skibbroen var der maksimalt plads til 8 familier. I perioden fra 1929 til 1934 aftog presset på husvildebarakkerne. Nu blev der kun indberettet et gennemsnit på 24 familier på ialt 122 personer, hvoraf dog stadig de 71 var børn under 15 år. $^{25}$ For perioden 1935 til 1941, foreligger der ingen opgørelser. Derimod er der for juli 1942 opgjort, at ialt 31 familier boede i kommunens husvildebarakker, heraf de 24 i barakkerne ved Renovationsanstalten. For den resterende periode fra januar 1943 til 1. halvår 1953, hvor den sidste barak ved Farversmøllevej forsvandt, ${ }^{26}$ indberettedes der følgende antal familier under kommunal boligforsorg. ${ }^{27}$

Af tallene fremgår, at der var et maksimalt pres på husvildebarakkerne i

Tabel 2

\begin{tabular}{lllc}
\hline Arstal & Antal familier & Antal personer & heraf børn u. 15 år \\
\hline Januar 1943 & $33^{*}$ & 171 & 89 \\
Okt. 1943 & 31 & 161 & 89 \\
Januar 1944 & 32 & 166 & 91 \\
Okt. 1944 & 36 & 184 & 100 \\
Januar 1945 & 35 & 180 & 99 \\
Okt. 1945 & 30 & 149 & 70 \\
Januar 1946 & 32 & 155 & 76 \\
Okt. 1946 & 30 & 141 & 72 \\
Januar 1947 & 30 & 141 & 72 \\
Okt. 1947 & 18 & 93 & 47 \\
Januar 1948 & 18 & 97 & 47 \\
Okt. 1948 & 18 & 96 & 40 \\
Januar 1949 & 17 & 75 & 34 \\
Okt. 1949 & 7 & 27 & 12 \\
Januar 1950 & 6 & 24 & 11 \\
Okt. 1950 & 6 & 24 & 13 \\
Januar 1951 & 6 & 24 & 13 \\
Okt. 1951 & 7 & 26 & 14 \\
Jan. 1952 & 7 & 26 & 14 \\
2. halvår 52 & 2 & 11 & 7 \\
1. halvår 53 & 0 & 0 & 0 \\
*) Af de 33 boede på Lindsnakkevej 47a & 5 & 25 & 11 \\
Foruden disse boede der sammen med & & & 28 \\
$\quad$ andre familier i én lejlighed & 22 & 74 & 117 \\
Der var således i januar 1943 ialt & 55 & 245 & \\
$\quad$ under kommunal boligforsorg. & & & \\
\hline & & & \\
\hline
\end{tabular}




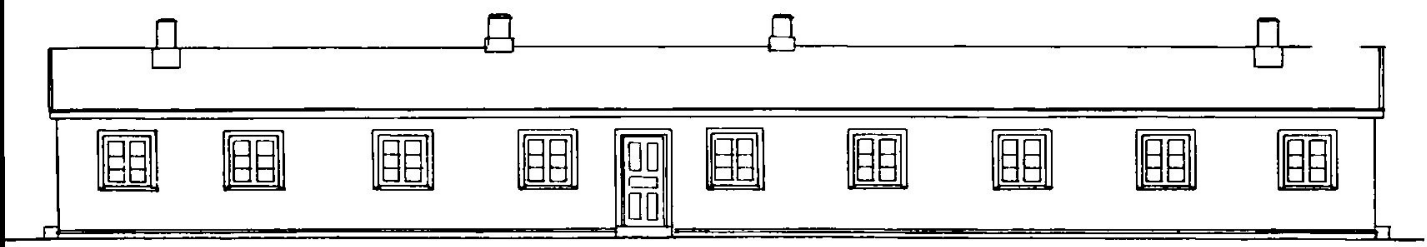

SIDE

Husvildebarak pa Farversmollevej. Tegning i Aabenraa byarkiv 1920-70 pk. 11-2.

perioden fra oktober 1944 til juli 1945, hvorefter det igen faldt til omkring 30 . På samme tid blev der truffet principbeslutning om nedrivning af barak nr. 4, hvorefter man tog fat på at omflytte beboerne til bl.a. de nyopstillede beboelsesvogne i området og til de ved Sønderskovvej i 1943/44 opførte stenbarakker. ${ }^{28}$

Flytningen tog tid. Men den 27. april 1946 kunne det så endeligt slås fast: om fjorten dage fjernes den første af de

"meget uhyggelige Barakker ved Farversmøllevej, som gennem Aarene har været anvendt til Menneskeboliger, men som nu er i en saadan Forfatning, at det ikke mere kan forsvares at anbringe Mennesker i dem «. ${ }^{29}$

Alligevel gik der yderligere fire år, nemlig til 1950, førend den næste af Farversmøllevej-barakkerne blev nedrevet, og endnu en gang et par år, inden hele komplekset var fjernet. Foruden opbruddet ved Farversmøllevej, hvor Aabenraa Andelsboligforening stod på spring for at bygge, skete der også ting og sager ved Lindsnakkevej, hvor Kolstrup Boligforening efter en arkitektkonkurrence i november måned 1947 havde udarbejdet et større byggeprojekt, som i 1949 krævede fjernelsen af den på stedet stående husvildebarak. ${ }^{30}$

Hvor mange familier, der i tidens løb har beboet barakkerne ved Farversmøllevej, har det ikke været muligt at fastslå helt nøjagtigt. I alt har det været ca. 140 familier eller ca. 700 personer. Lejemålenes varighed fordelte sig sådan: Tabel 3

\begin{tabular}{lllll}
\hline & & \multicolumn{3}{l}{ Heraf var bosiddende i perioden: } \\
\cline { 2 - 5 } Antal år i barakkerne & Antal familier ialt & $1923-25$ & $1925-29$ & $1929-53$ \\
\hline $0-5 \mathrm{ar}$ & 105 & 16 & 21 & 68 \\
$5-10 \mathrm{ar}$ & 22 & 1 & 5 & 16 \\
$10-15 \mathrm{ar}$ & 6 & 1 & 0 & 5 \\
$15-20 \mathrm{ar}$ & 5 & 0 & 0 & 5 \\
$20-25 \mathrm{ar}$ & 1 & 0 & 0 & 1 \\
$25-30 \mathrm{ar}$ & 1 & 0 & 1 & 0 \\
\hline & 140 & 18 & 27 & 95 \\
\hline
\end{tabular}

Kilde: Aabenraa Byarkiv 1920-70 pk. 11-2.

Aabenraa Adresse/skattebog og Aabenraa Vejviser 1923/24-53. 
Af tabellen fremgår, at af periodens 140 lejepartier boede de 105 familier der kun $\mathrm{i}$ op til 5 år, en stor del heraf endda i mindre end et år. Ingen af familierne kom til at bo $\mathrm{i}$ barakkerne $\mathrm{i}$ hele perioden på 29 år. Men der var dog én familie, som boede derude i 28 år, og én i 21 år.

Ser vi på beboernes erhvervsfordeling, giver det følgende gennemsnitsværdier for perioden 1924-52:

Tabel 4

\begin{tabular}{lllllll}
\hline Periode & Arbejdsmænd & Husassistenter & Enker/Hustruer & Retenydere & Faglærte & Andre \\
\hline $1924-25$ & $58,3 \%$ & $4,2 \%$ & $8,3 \%$ & $4,2 \%$ & $12,5 \%$ & $12,5 \%$ \\
$1929-40$ & $61,5 \%$ & $3,8 \%$ & $3,8 \%$ & $3,8 \%$ & $15,4 \%$ & $11,5 \%$ \\
$1942-46$ & $47,5 \%$ & $12,5 \%$ & $5,0 \%$ & - & $12,5 \%$ & $22,5 \%$ \\
$1947-49$ & $50,0 \%$ & $3,1 \%$ & $9,4 \%$ & & $12,5 \%$ & $25,0 \%$ \\
$1950-52$ & $41,7 \%$ & - & $16,7 \%$ & & $16,7 \%$ & $25,0 \%$ \\
\hline
\end{tabular}

Kilde: Aabenraa Adressebog/Vejviser 1924ff.

Tallene er ikke videre overraskende og bekræfter kun én gang mere det forhold, at de "mandlige beboere bestod af enkelte håndværkere men overvejende af arbejdere uden uddannelse«. De her forsamlede »var småkriminelle, ærlige og stræbsomme, flittige og dovne. Her var klunsere og plattenslagere ${ }^{31}$

\section{Baraklivet}

Ifølge dommeren i Aabenraa skal stridigheder beboerne - men altså navnlig kvinderne - imellem have været »et hyppigt forekommende forhold «, i al fald $\mathrm{i}$ begyndelse af 30'erne. Om de vitterligt var så hyppige, ved kun beboerne selv. Arkiverne tegner ikke et sådant billede. I al fald har jeg kun kunnet finde et par enkelte breve fra beboerne til kommunen, hvori sådanne stridigheder optræder.

Af de mig bekendte sager fandt den første sted i $1924 .{ }^{32}$

I Brevet til »Hr. Borgmesteren« af 9. marts 1924 hedder det:

„Undertegnede tillader sig herved at indgive en klage over Fru $\mathrm{H}$ ... og Fru I ..., som i de sidste Dage har raabt de sjofleste ord efter B ... og Hustru, samt flere andre Familier som ogsaa bliver besværet af Fru $\mathrm{H}$... særlig, som er den der har sat det hele igang inde hos Fru I ... Naard vi skal hente Vand ved Pumpen bliver der raabt og skreget de mest brutale ord saasom Horekvinde og deslige. Da vi ikke selv kommer sammen med disse Familier og allermindst kender Fru I ... kan vi dog ikke faa Lov til at gaa i Fred. 


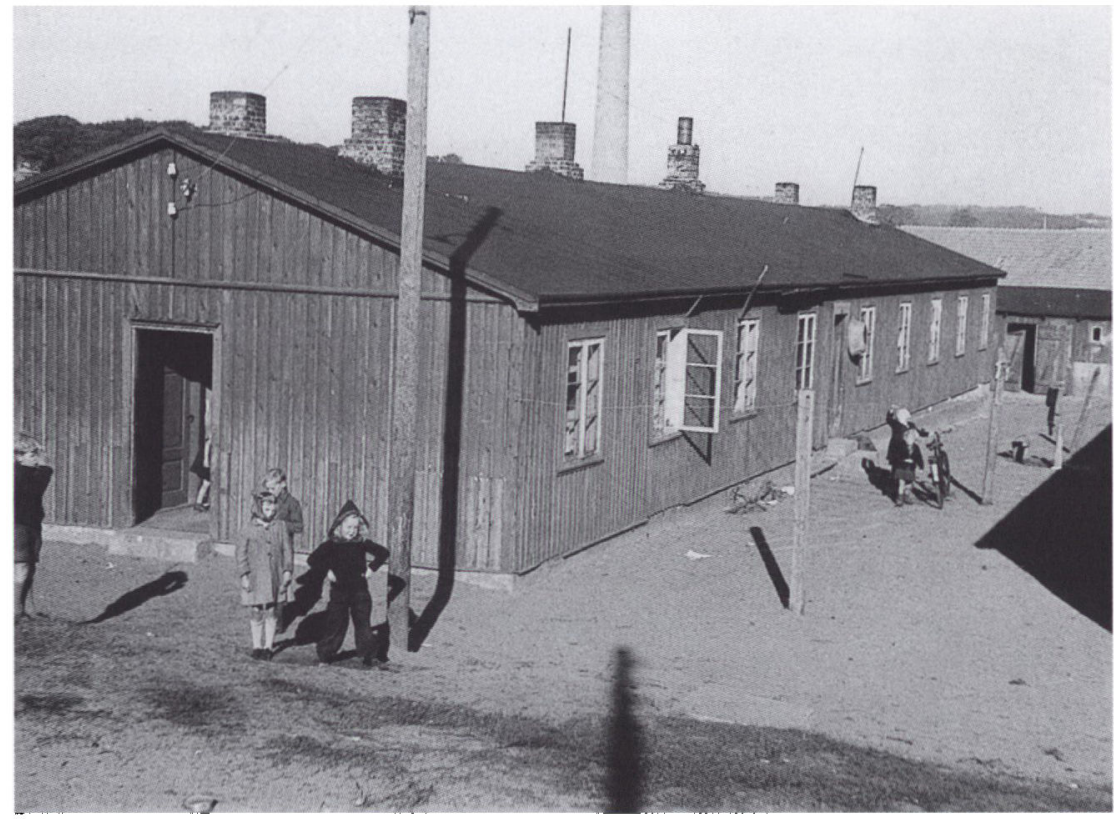

Barakken ved Farversmollevej. Foto: Institut for sonderjysk lokalhistorie.

Vi beder derfor Hr. Borgmesteren Høfligst om at tage sig af denne Sag da det er os formeget af det gode: B ... har søgt hos Fru I ... for at faa Grunden at vide men blev overøst med de mest beskidte Ord. Hertil bevidnes

A.S; H.M.M.; J.A.L.; H.P.S.; O.L.; L.S

Ærbødigst H. B.

Lidt senere blev denne klage fulgt op af et brev fra yderligere ét vidne. Brevet er udateret:

"I henhold til denne Beklagelse af $\mathrm{H}$. B. over I's Kone angaaende Fornærmelser i høj grad, kan jeg bekræfte at det beror paa Sandhed og da jeg er en syg mand og lider af en Sygdom som ikke kan helbredes lider jeg meget af denne Skjæbne, saa det var en megen Velgjærning at, vis Herr. Magistraten vilde gjøre det mulige for at jeg som syg Mand Kunde faa den nødige Ro over for en saadanne rasende Kvinde, som ogsaa Truer med, at ved forste Lejlighed, vil overfalde vores lille 3-aarige Dreng; jeg bor i samme Dør som I 


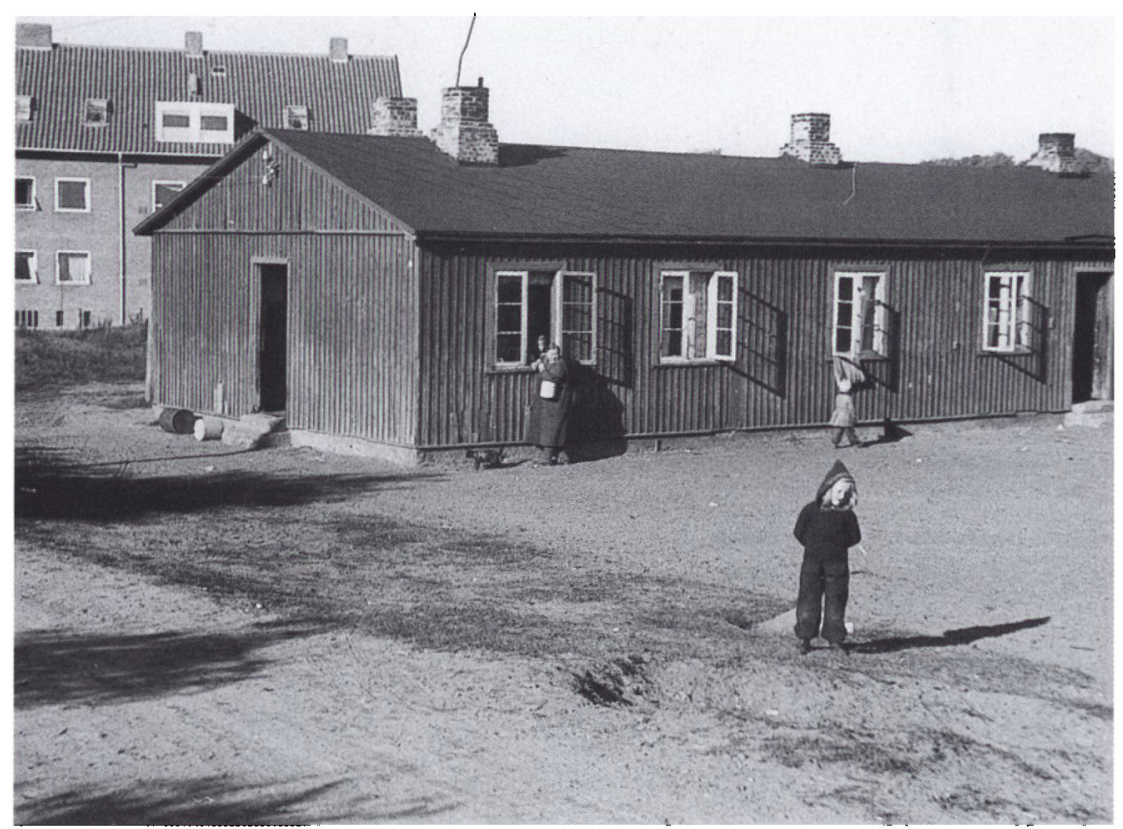

Barakken ved Farversmollevej. Foto: Institut for sonderjysk lokalhistorie.

..., og maa døje mest, jeg er syg, og beder om Herr. Magistratens naadige hjælp med at give dette Familie en Lejlighed, hvor dette Familie kunde udrase. Børnene lider af en urenlig udslet saa det staa ogsaa fare for, at vi kunde besmittes.

Invalid A.

I den høje magistrat blev sagen taget til efterretning og lagt ad Acta.

Om der senere er kommet ro over gemytterne vides ikke. Sandsynligheden taler imidlertid ikke for en sådan udgang på opgøret. "Den rasende Kvinde« fraflyttede først februar $1926 \mathrm{og}$ fru H. med familie så sent som december 1927 - uden at kommunen dog på noget tidspunkt ser ud til at have grebet regulerende ind i konflikten. Klageren fraflyttede først april 1927.

Allerede i 1930 eskalerede en ny konflikt, denne gang i barakken ved siden af. Der blev indgivet et andragende til amtmanden, Kresten Refslund Thomsen, fra fru C. B., om fri proces i en sag om gener påført naboerne $i$ barak nr. 1 af familien H. A. Tidligere henvendelser til kommunen havde kun ført til, at man havde henvist beboerne til at rette henvendelse til politiet.

Andragendet om fri proces $\mathrm{og}$ beskikkelse af en sagfører til at anlægge sagen blev imidlertid afvist, idet dommeren, Chr. Andersen, ikke mente at kunne 
anbefale meddelelse af fri proces. Det var hans opfattelse, at beboerne var et så »eget Folkefærd«, at stridigheder af den foreliggende art aldrig ville kunne undgås, hvorefter han i stedet tilstillede sagen Aabenraa Byråd til udtalelse. Her blev sagen behandlet af forsørgelsesudvalget. Men også det nåede frem til den erkendelse, at windbyrdes Skænderi imellem Barakkens Beboere ... ikke ville kunne undgaas«. En anmodning om omflytning af den genstridige familie strandede på de anstrengte pladsforhold i barakkerne, hvorfor byrådet ikke så sig »i stand til at anbringe (familien) $i$ en anden lejlighed«. Således besluttet og lagt ad acta af Aabenraa Byråd på dets møde den 24. sept. 1930.

En fornyet klage mod samme familie fremkom i 1933, nu også rettet mod to andre familier. I brevet til byrådet hedder det, at man stadig ingen ro har kunnet få for disse familier, ja at det »tvertimod blir ... verre for ver Dag“ der går, hvorfor man nu altså igen henstiller til byrådet, venligst "at sørge for Ro«. Herefter fortsætter brevet:

"Saasnart vie sender vores Børn ud at lege saa er A's Børn der med store Sten og kaster efter dem helt ind $\mathrm{i}$ vores Leiglighed og klager vie saa til Forældrene saa sir de at de har die Lov til naar vie gaar forbi Vinduerne efter Vand saa sidder alle tre Fruer inden for Vinduet og faar Børnene til at rekke Tunge efter os og skelder os ud for Sigøjnere og beskitte Pak og deslige jeg ved ikke om vie skal blive ved at finde os i det. Alle Folk er bange for Dem herude men der er ingen der vil klage over Dem mere da die siger det er bleven gjort flere gange men ikke hjulpet noget saa jeg kanss ikke forstaa vorfor die stor i saa godt et Lys i Byraadet da die kanss faa Lov at blive siddende derovre med to Børn vor der sidder Familier herude i to Rum med 3-4 Børn. For at die støtter Dem paa at Byraadet ikke kann faa Dem ud da Die holder Deres Leilighed pene saa er der vel ikke noget at takke Dem for da die kun har 2 store Børn og vie andre 4-5 smaa Børn og vie andre har vel ogsaa faaet Leiligheden gjort i Stand. Og vores Havejord har vie heller ingen Nytte af da vie ikke kan holde Børnene borte derfra die overkaster Dem med Sten og andet Skrammel og gør Havelaagen og alt Traad og vad vie ellers har i Stykker og Forældrene morer Dem over det. Naar det begynder at blive mørkt faar den store Fritz A. alle de andre Børn med og saa gaar det løs med at kaste Sten paa vor Mands Forstue og ellers gaar die rundt og prikker paa vores Vinduer. Nu ved jeg ikke om Byraadet vil sørge for Ro da det er umuligt at have saadan nogle Naboer.

Erbødigst M.; V.; V. og J.« (signeret af fire fruer) 
Men ak nej. Ej heller denne gang mente kommunen, at den kunne gribe ind og hjælpe beboerne. Man skal, hedder det $\mathrm{i}$ brevet fra magistraten af 2 . febr. 1933, "herved meddele Dem, at man fra Kommunens side ikke ser sig i Stand til at foretage sig noget i denne Sag, men maa henvise Dem til Politiet«.

Hvad der herpå skete i sagen er ikke oplyst. Men da de tre anklagede familier ikke mere er noteret $\mathrm{i}$ barakkerne året efter, kan man vel slutte, at forholdene igen blev normale.

Hvor lidt vilkårene ændrede sig i tidens løb, viser et sidste brev, denne gang dog ikke skrevet til kommunen, men til Boligministeriet af en 73-årig syg kone. Brevet er fra $1951 .{ }^{33}$ Hun var i 1924 med sin mand og flere børn flyttet ind $i$ de dengang nyopførte barakker, og havde altså boet dér i hele 27 år. Året efter boede hun der stadig med en af sine sønner. I brevet hedder det:

"Jeg er en gammel syg kone på 73 år. Jeg har siddet i 1 værelse med køkken og har en søn boende hjemme, som er invalid. Ialt har jeg boet i disse værelser i en husvild barak i 27 år ... Jeg lider af kronisk astma og åben sår på begge mine ben, derfor synes jeg, at jeg skulle hen $\mathrm{i}$ mere rolige forhold. Mine fødevarer har jeg $\mathrm{i}$ et hul $\mathrm{i}$ jorden under gulvet, og min invaliderente skal jeg dele med min søn ..., da jeg ikke kan være alene, og så står der en pumpe lige uden for mit vindue, hvor der hentes vand til 8 familier. Om morgenen kommer naboerne og vasker sig lige uden for mit vindue. Dagen igennem leger børnene med pumpen. Når jeg prøver at jage dem væk, siger de blot, hold snut gamle kvind, og smider vand op på mine vinduer, mens forældrene står og ler af det«.

Billedet er det samme, som det har været hele tiden: børn og voksne, der generer deres medbeboere, snuttede bemærkninger og leende forældre - og en henvendelse til øvrigheden, som ikke førte til noget. Som i de forgangne 27 år opbevarede hun stadig sine fødevarer i »et hul i jorden under gulvet«. Vandet skulle stadig hentes ved pumpen $\mathrm{i}$ gården og nødtørften skulle stadig klares $\mathrm{i}$ ritiradens latrinspande. Sådan klarede i årenes løb mellem 150 og 160 familier sig, indtil barakkerne i 1952/53 måtte vige pladsen til fordel for Aabenraa Andelsboligforenings boligblokke på Fuglsang, som adressen blev ændret til i 1947. At privatlivets fred altså ikke altid blev respekteret, således som påstået af Fred Vilhelm Schmidt i sin erindringsbog, ${ }^{34}$ bevidner de anførte breve meget tydeligt. Også fordrageligheden led fra tid til anden skibbrud derude.

Men alligevel var det nok mere undtagelsen end reglen. I det store og hele har barakkerne nok ikke været noget udsøgt dårligt sted at bo. Fred Vilhelm Schmidt har sikkert ret $i$, at en barakbolig "på flere måder var at foretrække 
frem for en bybolig «. Hvor man inde $\mathrm{i}$ byens mange, ofte fugtige og usunde stenhuse $^{34 a}$ kunne komme ud for, at børnene led af lungebetændelse, mellemørebetændelse o.l., forekom den slags overhovedet ikke i barakkerne. Og blev man endelig syg alligevel, så var det $\mathrm{i}$ al fald - når man skal tro de tidligere beboeres fortællinger - ikke fordi husene $i$ sig selv var usunde at bo $i$, men snarere fordi udenomsforholdene var som de var.

Betegnende er det $i$ al fald, at af de to eneste konstaterede besøg af sundhedskommissionen derude, beskæftigede ingen sig med husenes eller menneskenes usundhed, men alene med møddingens beskaffenhed, og med et problem om 》overbelægning « $i$ én af barakkernes lejligheder i $1933 .{ }^{35}$ Hvorfor sundhedskommissionen netop var ude for at se på lige præcis den lejlighed, der sikkert har været en af de mindst overbelagte $\mathrm{i}$ barakkerne, som det år $\mathrm{i}$ snit husede 5,2 personer pr. lejlighed, kan godt undre. Forklaringen er nok, at beboeren, den før omtalte 73-årige syge kvindes ægtemand, stod for at skulle forlade arbejdsmarkedet. Han fik formentlig da overladt lejligheden som fribolig, og derfor nok også sundhedskommissionens besøg.

\section{Elektricitetens vej til barakkerne}

Efterhånden som elektrificeringen af Aabenraa by tog til, begyndte også beboerne i husvildebarakkerne meget forståeligt at kræve elektrisk lys. Ved Genforeningen i 1920 var el godt på vej i den indre by. Alligevel fik hovedparten af byens befolkning stadig sit lysbehov dækket gennem gas fra Gasværket. Også gadebelysningen var stadig gasværkets sag - og det helt frem til og med 1928. Foruden gassen anvendte man også petroleum til belysning og kogning. Dette ændredes der ikke stort ved, før Sønderjyllands Højspændingsværk blev sat i drift i 1924. Allerede i sommeren 1927 var der således i Aabenraas 933 huse og deres lidt over 2.300 lejligheder blevet installeret i alt 2.085 lysmålere og 22.734 lampesteder, hvortil kom 190 kraftmålere, idet bygassen længe forblev borgernes foretrukne energikilde til kogning. ${ }^{36}$

I husvildebarakkerne gik udviklingen imidlertid knap så hurtig. Derude var i 1932 stadig petroleumslampen den eneste lyskilde - og så naturligvis, som et bestemmende element for de udendørs aktiviteter, Månen, idet der på disse beboeres veje og stier ingen lygter brændte. De var som landbofolket $i$ tidligere tider havde været det, stadig henvist til at indrette deres udendørs "Arbeider og Ekspeditioner efter Maaneskiftet«, som der står i en ældre astronomibog. ${ }^{37}$

Den første henvendelse til magistraten om installering af elektrisk lys blev undertegnet af 16 ud af barakkernes 25 familieoverhoveder den 31. maj 1932. Brevet indeholdt også en finansieringsplan. ${ }^{38}$ Andragendet blev forelagt byens 


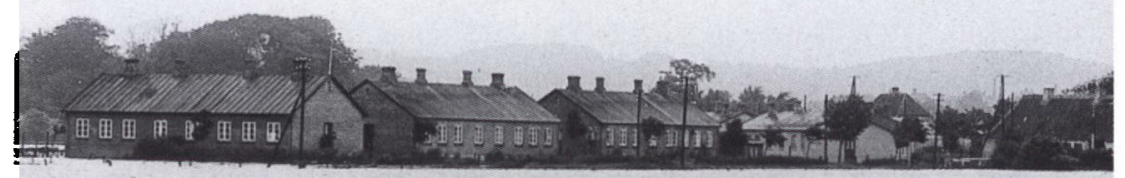

a.

Husvildebarakkerne ved Farversmollevej var ikke de eneste i Aabenraa. Her ses stenbarakkerne Bag Mollen/Langebro fotograferet i 1931. Foto i Institut for Sonderjysk Lokalhistorie.

forsørgelsesudvalg til udtalelse. I udvalgets indstilling til magistraten hedder det, at »Udvalget efter indgaaende Drøftelser« ikke mente at kunne anbefale sagen, da bygningerne jo kun var »Nødhjælpsboliger«, som man ikke ønskede "videre moderniseret«. Denne begrundelse blev tiltrådt af magistraten og derpå tilstillet beboerne $\mathrm{i}$ barakkerne med ordene, at "man under Hensyn til, at Bygningerne kun er beregnet som "Nødboliger«, ikke så sig i stand til at imødekomme andragendet.

En sådan besked kunne beboerne selvsagt ikke være tilfredse med. Alligevel så de tiden an, før de igen i 1933 rettede henvendelse til magistraten. Denne gang dog uden en finansieringsplan, men udbygget med en begrundelse om petroleumslampernes brandfarlighed og sundhedsmæssige risiko for de sovende born. Det hedder i brevet, at de »beder om en velvillig behandling af Sagen, da Brandfaren dog er overhängende med Petroleumslamper og at det af Sundhedshensyn jo ogsaa vilde väre en Forbedring saa Börnene ikke behövede at sove $i$ et Værelse med en osende Petroleumslampe«.

Denne gang var brevet underskrevet af 20 ud af ialt 23 familiers overhoveder. Men heller ikke nu frugtede henvendelsen. Forsørgelsesudvalget holdt stadig på, at det "af principielle Grunde ikke kunde anbefale Andragendet«, hvorpå magistaten afslog anmodningen. Afslaget blev afsendt til beboerne i et ligelydende brev som året $\mathrm{i}$ forvejen!

Men dermed var sagen langt fra afgjort. Endnu et brev blev skrevet. Denne gang af hovedmandens hustru. Hun havde meget passende valgt julens forestå- 
ende komme til at opbløde de kommunale magthaveres hårde hjerter. Hun skrev:

Aabenraa den 7. Dec. 33

Til Magistraten!

Undertegnede beder om at faa denne Sag taget velvillig til Behandling, da det er et Jule Ønske. Vi sidder Allesammen og er skuffede over at Vi ingen Lys maa faa. Barakkerne har nu staaet i 11 Aar og de staar nok 11 til, derfor synes jeg vi kunde passende faa det nu til Jul. Jeg var i Gaar i Byen og saa alt det Lysreklame som bliver gjort nu til jul. Vi heroppe vil ogsaa nok have lidt af Livets goder. Allesteder bliver der averteret (köb Elektrisk Kökken), og vi faar ingen Ting.

Det blev engang for 11 aar siden sagt til mig Folk som ikke betaler har ingen Rettigheder men nu har vi betalt og har heller ingen Rettigheder. Jeg vilde Önske at Kommissionen kom herop en Aften naar det er rigtig mörk og saa, sig det hele an. Udenfor gaar man og falder og indenfor sidder man ved Maaneskin, og bliver sorte i Hovedet, nej de kan tro det er trist, og nu lige ind til Jul hvor vi allesammen har travlt. Jeg er af den Mening Vi maa ogsaa faa godt af det inde fra Byen, heller bliver Vi regnet for Andenklasses Folk, det bliver jo ogsaa kaldt (Vridslöslille) heroppe men jeg mener dog, at der har de Lys, et Lys uden for paa Vejen er vi jo dog bleven lovet, men har inu ikke faaet det, nu haaber Jeg at faa Önsket opfyldt det er dog ogsaa Jul heroppe, det er trist nok enda.

Med Agtelse N. A.

Dette gribende brev blev overgivet det tekniske udvalg til udtalelse. Resultatet blev en magistratsbeslutning, der blankt afviste andragendet; en afvisning hun dog ikke måtte få på skrift! Efterretningen blev, som det står anført, givet hende mundtlig. Herefter ophørte henvendelserne - uden at noget dog skete.

Pausen varede indtil 1936. Nu tilskrev beboerne igen kommunen. Ud over de førnævnte begrundelser og henvisningen til »at Husvildebarakkernes Levetid ud over den først paatænkte, synes at forlænges i det uvisse«, fremførte initiativtageren, »at elektrisk Belysning istedet for Petroleumslamper « også "vilde betyde et stort økonomisk Plus«. Dertil kom, at lysledningerne inde fra byen nu var ført helt ud til, hvor barakkerne lå, således at der vel ikke længere af den grund wskulde være stort til Hinder for vort Ønske. Hvor der er Vilje, 


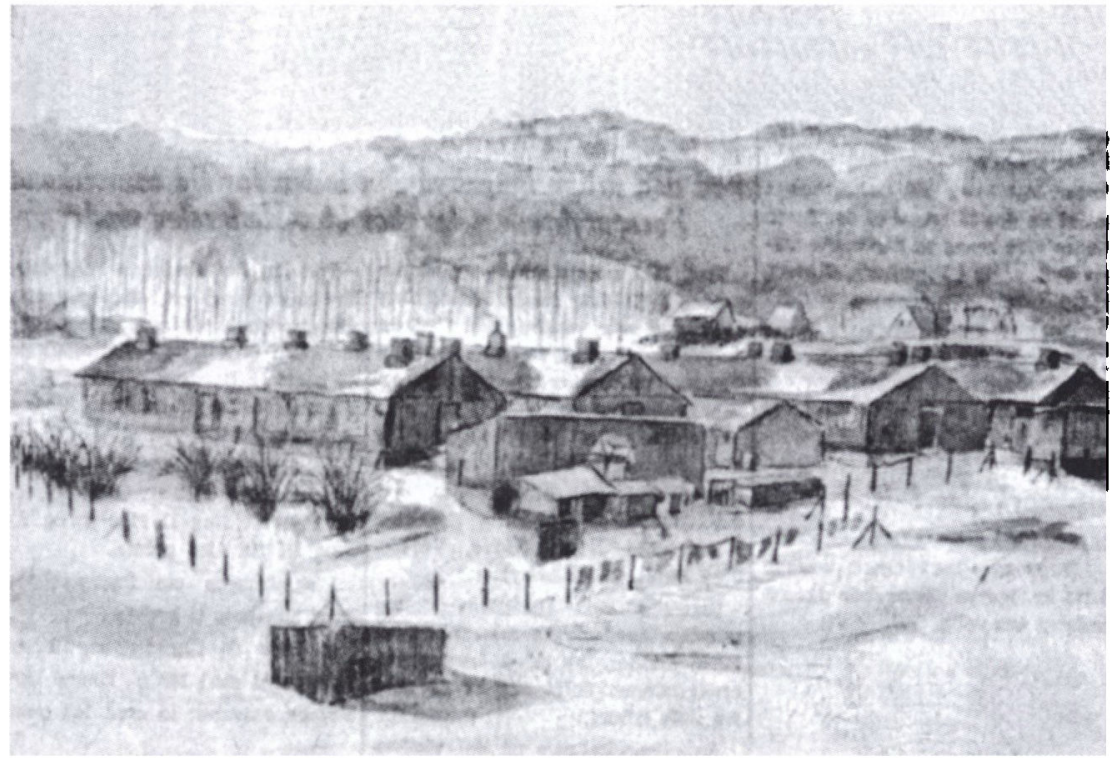

Husvildebarakkerne ved Fuglsang forsvandt 1952-53. I 1946 malede formanden for Aabenraa Andelsboligforening, viceskoleinspektor Jorgen Stave, denne akvarel af bebyggelsen.

er der ogsaa en Vej«, fremhævede brevskriveren i brevet, som denne gang var underskrevet af samtlige beboere på nær én lejer.

Endelig frugtede anstrengelserne. Den 29. september 1936 vedtog byrådet på et lukket møde at imødekomme andragendet. Ifølge beslutningen skulle byen betale udgifterne ved installationen, Beboerne derimod skulle alene betale en fast afgift for lysforbruget. Der skulle etableres 72 lampesteder, heraf de 66 i lejlighederne, der hver også skulle have to stikkontakter. Aflæsningen af målerne skulle foretages af socialkontoret hver uge. Forbruget skulle indføres i en kontrolbog og betales straks ved aflæsningen. ${ }^{39}$

\section{Afrunding}

I det foregående har vi fortalt historien om nogle af de husvildebarakker, som fandtes i Aabenraa i årene fra 1922 til 1953. Det er sket, bl.a. fordi barakfænomenet var ganske udbredt netop i Aabenraa. Ifølge statistikkerne lå over 2/3 af Nordslesvigs registrerede husvildebarakker her. Også sammenholdt med provinsbyerne i almindelighed var andelen af baraklejligheder særlig stor i Aabenraa. ${ }^{40}$ 
Det har vist sig, at husvildebarakkerne først og fremmest blev bygget for at skaffe boliger til de lejere, som var sat ud af deres boliger på grund af huslejerestancer. Men selvfølgelig lå der også en generel mangel på boliger til mindrebemidlede som årsag til barakkernes oprettelse.I det hele taget kneb det i Aabenraa med de tiltag, som f.eks.i Sønderborg og Tønder hurtigt gjorde husvildebarakkerne overflødige, nemlig dannelsen af almennyttige boligforeninger. I Aabenraa kom man først i gang efter 2. Verdenskrig. Andelsboligforeningerne satte dermed punktum for dette kapitel. I 1952/53 veg de sidste husvildebarakker ved Farversmøllevej for ejendomme under Aabenraa Andelsboligforening. Et kapitel af socialhistorien var dermed nået til en afslutning.

\section{NOTER OG HENVISNINGER}

1. Således meddelt $i$ et brev af 7.12 .1934 fra en af beboerne til magistraten. (Aabenraa Byarkiv 1920-70, pk. 11-2).

2. Aabenraa Byarkiv 1920-70, pk. 11-2.

3. Jvf. Hejmdals artikel den 5.2.1947, da renovationsanstalten nedbrændte til grunden.

4. Fred Vilhelm Schmidts læserbrev i »Jydske-Vestkysten « 19.5.1994.

5. "Sønderborg Bys Historie巛, bd. II, 1966, p. 102;

"Tønder gennem Tiderne«, 1. Halvbind, 1943, p. 305f. og 313; Henrik Becker-Christensen: "Byen ved grænsen«. Tønder 1920- 70, 1993, p. 253.

6. Forfatteren fraflyttede barakkerne i seksårsalderen, og bogen er som øjenvidneskildring derfor ikke af sarlig vardi vedr. baraklivet.

7. Jvf. brev til undertegnede af 31.05.1994. Således også det fø̊lgende citat af E.J.

8. Aabenraa Byarkiv 1920-70, pk. 37-3-4 I.

9. Aabenraa Byarkiv 1920-70, pk. 37-3-4 I.

10. Hejmdal 18.7.1924.

11. Aabenraa Byarkiv 1920-70, pk. 11-2.

12. Schultz Danmarkshistorie, bd. VI, 1943, p. 419.

13. Statistiske Meddelelser 4. Rakke, 68. og 70. Bind, Kbh. $1923 \mathrm{f}$.

14. Aabenraa Adressebog (Skattebog) for $1922 \mathrm{f}$.

15. Aabenraa Byarkiv 1920-70, pk. 37-3-4 I.

16. Hejmdal den 24.1.1924.

17. Aabenraa Byarkiv 1920-70, pk. 11-2.

18. Aabenraa Byarkiv 1920-70, pk. 37-3-4 I.

19. Aabenraa Byarkiv 1920-70, pk. 11-2.

20. Fred Vilhelm Schmidt: Fra de røde barakker, Attika 1993, p. 27; leserbrev i Jydske Vestkysten den 19.5.1994 (jvf. i øvrigt også note 34a).

21. Aabenraa Byarkiv 1920-70, pk. 11-2.

22. Aabenraa Byarkiv 1920-70, pk. 11-2.

23. Hejmdal 24.01.1924 (jvf. i øvrigt note 34a)

24. Aabenraa Byarkiv 1920-70, pk. 11-2.

25. Aabenraa Byarkiv 1920-70, pk. 37-3-4 I.

26. Men dermed dog ikke også de sidste barakker i Aabenraa, idet der stadig stod træbarakker $i$ Højgade indtil 1960 'erne.

27. Tallene gæelder fortsat kun familier $\mathrm{i}$ barakkerne ved Farversmøllevej og på Lindsnakke. Aabenraa Byarkiv 1920-70, pk. 37-3-4 I. 
28. Hejmdal 27.11.1945 og 1.12.1945; Aabenraa Vejviser 1946ff

29. Hejmdal den 27.4.1946.

30. Jvf. "Kolstrup Boligforening ved 25 års jubilæet «, 1968, p. 6f.; Svend Aage Faaborg: "50 års jubilæum. Kolstrup Boligforening 1943-1993«, 1993, p. 30f.

31. Fred Vilhelm Schmidt: Fra de røde barakker, 1993 p. 21.

32. Aabenraa Byarkiv 1920-70 pk. 11-2.

33. Henrik Becker-Christensen og Jørgen Witte: Fra Købstad til Storkommune. Aabenraa bys historie bind 4 1945-1970, 1985 p. 134. Brevet anføres at ligge i Aabenraa Byarkiv, pk. 22-1-1, hvor jeg dog ikke har kunnet finde det!

34. Fra de rede barakker, op. cit. p. 28.

34a.Hvoraf i 1928 dog kun ialt 15 lejligheder af sundhedskommissionen var blevet erklæret for uegnede til beboelse enten pga. usundhed eller pga. boligens faldefærdighed. Det drejede sig dengang om følgende lejligheder: fire 2-værelses lejligheder på adressen Nygade 62; fem 2-værelses på adressen Nygade 22 og 24; fire 2-værelses i baghuset til Slotsgade 14; en 2-værelses i kæideren på adressen Nyvej 3 og en 3-værelses lejlighed på adressen Nygade 22/24. Huslejen for sådanne 2-værelses lejligheder skal have været på ca. kr. 300,- pr. år (jvf. oplysningerne fra Aabenraa Byråd den 20.10.1928 til formanden for "Det Sønderjydske Erhvervsudvalg«, Aabenraa Byarkiv 1920-70. pk. 37-4.3.

35. I stedet for to voksne boede fire personer $\mathrm{i}$ denne 1-varelses lejlighed, som ifølge politiets brev til kommunen højst burde beboes af tre personer.

36. Aabenraa bys historie bd. 3 p. 35, 148 og 152. Trap Danmark bd. IX, 1930 p. 413.

37. J. C. Tuxen: "Sol og Planetsystemet«, 1861, p. 168.

38. Aabenraa Byarkiv 1920-70 pk. 11-2.

39. Aabenraa Byarkiv 1920-70 pk. 11-2.

40. Statistisk Aarbog 1925-31. Statistiske Meddelelser: Husleje og boligforhold. Nov. 1924-Nov. 1929. Kbh. 1925-30. 